\title{
Biotechnological Interventions for Sustainable Conservation of Plant Genetic Resources in the Scenario of Climate Change
}

\section{R. K. Salgotra*, Manmohan Sharma ${ }^{1}$, Pankaj Pandotra ${ }^{1}$}

School of Biotechnology, Sher-e-Kashmir University of Agricultural Sciences \& Technology of Jammu, Chatha, Jammu-180009 (J \& K), India, rks_2959@rediffmail.com

\section{ABSTRACT}

Climate change is an unequivocal fact and its impacts are already perceptible today. Climate change will profoundly alter the present conditions of agriculture in almost all countries with variable severity from region to region. On one hand unpredicted changes in climatic parameters are likely to threaten the production and productivity of economically important plant species particularly that of food crops, at the same time agriculture productivity requires significant increase to meet the expected growth in demand for food by the ever increasing world population. Conservation and sustainable use of diversity present in plant genetic resources and traditional knowledge of germplasm within and among plant species represent economic, scientific and societal value which has tendency to solve the food security problems erupt due to expanding global population. An advance made in biotechnology field such as in vitro culture technology, cryopreservation and molecular markers technology has generated significant contributions to improve the methods of conservation of rare and endangered plant genetic resources and traditional knowledge of germplasm and their valuable management in an effective way. A strategic and forward vision for conservation of plant genetic resources and traditional knowledge of germplasm and sustainable use of plant resources in the 21 st century is of far reaching significance for sustainable development.

Keywords: Plant Genetic Resources; Biotechnological Interventions; Sustainable Conservation; Climate Change

\section{Introduction}

International Undertaking on Plant Genetic Resources (FAO, 1983) defines PGR as the reproductive or vegetative propagating material of (i) cultivated varieties (cultivars) in current use and newly developed varieties; (ii) obsolete cultivars; (iii) primitive cultivars (landraces); (iv) wild and weed species, near relatives of cultivated varieties; and (v) special genetic stocks (including elite and current breeder's lines and mutants). CBD (1992) implies genetic resource to be any "genetic material of actual and potential value", and genetic material to be a "functional unit of heredity". PGR include materials considered of systematic importance and applicable in cytogenetic, phylogenetic, evolutionary, physiological, biochemical, pathological and ecological research and breeding. They encompass all cultivated crops and those with little to no agricultural value as well as their weedy and wild relatives (Ulukan, 2011).

PGR are the building blocks for the improvement of agricultural and industrial crops, and the agro-processing sector. PGR are the pillars upon which world food security depends especially with expanding global population (Ogwu et al. 2014). PGR constitute a rich gene pool of agronomically important traits having potential for improving plant yields and combating a battery of biotic and abiotic stresses to which plants are exposed under field condition during their life cycles. The growing global demand for food and bio-based renewable materials, such as bio-fuels, is changing the conditions for PGR development and bio-resource production worldwide. Gross domestic product (GDP) of many developing countries depends on agriculture sector, sustainability of which relies on the rich wealth of plant genetic resources. Feeding the ever increasing population is a great challenge confronting many parts of the world, but the problems are worst in sub-Saharan Africa, where there has been stagnation and even decline in the agricultural productivity of small-scale farmers. 
Conservation, improvement and sustainable use of PGR are the components of a complex system in a dynamic interaction which is based on relationships among different types of representatives with specific functions within a system called the "Plant Genetic Resources System". Indigenous communities, research institutions, breeders, private seed companies, curators, collectors and farmers are the different representatives in the PGR system which perform functions with in a framework of legal rules. Only a systems approach, that studies not only the single components, but also considers the interplay among them, can, in fact, indicate sustainable strategies to face the multiple challenges before humanity (Sonnino, 2017). Development and utilisation of the PGR base and the associated knowledge are central to such efforts. International conventions and treaties together with the rapid advances in bioscience including biotechnology have led to new avenues for the access to PGR and traditional knowledge (TK). The Convention on Biological Diversity (CBD) and World Trade Organization (WTO) / Agreement on Trade-Related Aspects of Intellectual Property Rights (TRIPS) have led to stringent mechanisms for access to PGR and protection of biological diversity.

The survey, collection, conservation and sustainable utilization of genetic resources in an organized way is the utmost responsibility of all the nations. For the best conservation and sustainable utilization of existing biodiversity for the benefit of society in a country, all the policy makers, planners and scientists have to be engaged to get the best out of it (Tanksley and McCouch 1997). With the introduction of newly developed crop varieties and domestication of crop species, the genetic diversity among the genotypes is declining (Hyten et al. 2009) leading to genetic erosion. In order to prevent vulnerability of crop species and genetic erosion, there is need to preserve and sustainably utilize these valuable collected germplasm (Frankel 1984). To have the maximum plant genetic diversity of the entire collected germplasm, the concept of developing core sets was introduced (Brown 1989). The evaluation and characterization of germplasm on the basis of morphological characters does not reflect the maximum genetic diversity, however, the use of molecular markers depict the maximum diversity at the genic levels (van Hintum 1999).

In India, particularly North West Himalayas are well known for their rich biodiversity of PGR among field and vegetable crops (Wani et al. 2003). Among the field crops there exists a wide range of diversity for scented /aromatic rice (Oryza sativa L.) including Mushkbudji, Safed budji, Qadir ganai, Black rice, Kamad, and Tila zag which are prominently grown in southern Kashmir particularly in specific areas of Kokernaag, Saagam, Larnoo, Khudwani, etc., and these places can be developed as hot spots for seed production by farmers thus helping in the in situ conservation of the valuable PGR. Basmati rice grown in Jammu region of Jammu and Kashmir is world famous for its palatability and aroma (Salgotra et al., 2015). Non aromatic rices such as Mehwan (Green), Laer Beoul and Red rice are also in great demand because the staple food of the local inhabitants being rice (Gupta et al., 2009). There also exists great genetic diversity among maize local land races in Gurez and parts of southern Kashmir which possess tolerance against biotic and abiotic stresses. Some of them include Anantnag Safed, Tangwin safed and Aru wuzg. Herbal vegetables grown in the state are wild garlic (Allium ursinum), top onion (Allium cepa L.), taraxacum (Taraxacum officinale) (Haand), mallow (Sochel), rumex (Rumex crispus) (Obuj) and red gourd (Cucurbita pepo) (Parim). Potatoes (Solanum tuberosum L.) grown in Hurpur (Shopian), rajmash (Phaseolus vulgaris L.) mixed with maize (Zea mays L.), local moong (Vigna radiate) and broad bean (Vicia faba) are potential pulse crops grown in pockets of Shopian, Uri, Bhaderwah, Mandi, Poonch, Budhal and Gurez (Salgotra and Gupta, 2005). Among under water vegetables, lotus stem (Nadroo) have rich potential due to great local demand. Kashmiri red chilly (Capsicum annuum L.), due to its bright red colour and moderate pungency, is very famous in industrial and processed products. It is grown over an area of more than 1700 ha and if exploited could form one of the most potential high value commodities for export.

Underutilized cereal crops like medicinal buckwheat and sweet buckwheat/duck wheat which are grown for human consumption also serve as the feed for livestock and poultry as well as green manure. The buckwheat honey has a very high potential in difficult hilly terrains of Leh, Zanskar, Gurez and adjoining areas to meet the livelihood and food security of the people (Wani et al., 2003). There is a vital need to pay attention for conservation and utilisation of these PGR which will further lead to improvement of food, nutritional and livelihood security of diverse inhabitants of 
Jammu and Kashmir state.

One of the tools used to enhance biodiversity is biotechnology. Biotechnology covers a variety of techniques and applications that allow changes and improvements in living organisms to provide desirable products for man's use. Biotechnology is used for the conservation, evaluation, and utilization of biodiversity particularly for important crops (Singh, 2000)

\section{Climate change and role of PGR in resilienec development}

Climate change is a stark reality being faced by humanity and its likely impacts on agriculture and related fields compel the scientific community to work towards innovating new technologies which would prove resilient during erratic changes in climatic situations. Climate resilience can be generally defined as the capacity for a socio-ecological system to absorb stresses and maintain function in the face of external stresses imposed upon it by climate change; and to adapt, reorganize, and evolve into more desirable configurations that improve the sustainability of the system, leaving it better prepared for future climate change impacts (Folk, 2006; Nelson et al., 2007). Climate change is a globally accepted unequivocal fact. Its impacts are already perceptible today and will intensify over the current century. According to the $4^{\text {th }}$ Report of the Intergovernmental Panel on Climate Change (IPCC) the global average temperature will rise between 1.8 and 4 degrees Celsius by the end of the $21^{\text {st }}$ century compared to an increase of about 0.75 degrees Celsius over the past century. Global and regional weather conditions will become more variable, with more frequent extreme events, expansion of areas with high climate variability and significant changes in precipitation patterns. The impact of climate change on agriculture will vary from region to region. Generally, changes in precipitation and rising temperatures are likely to lead to increased incidence and intensity of weeds, pests and diseases in cultivated areas. Higher temperatures are expected to increase the length of the growing season and the total area suitable for cultivation in temperate latitudes, especially in Europe and North America. However, possible yield gains in these regions have to be set against losses due to the spread of weeds, pests and diseases. Regions in lower latitudes will be most severely affected by a decline in land suitable for cultivation, especially sub-Saharan Africa and the Caribbean. In tropical and subtropical regions extreme seasonal heat is expected to severely lower agricultural outputs. Whatever the overall impact, one thing is clear: climate change will profoundly alter the present conditions of agriculture in almost all countries. Projections indicate that by 2050 many countries, making up about 35 percent of the global land area, will experience novel climates they have not been exposed to within their borders before. This suggests that climate change is happening so fast that crops and forage varieties in these areas are very unlikely to adapt to it on their own. Crops that have historically been doing especially well in a given region may no longer be of use and will have to be substituted by other crops: in sub-Saharan Africa for example, where maize is a major staple food crop at present, the land may not be suitable anymore for its cultivation by 2050 .

By 2050, the global population is expected to reach 9 billion people, requiring 70 per cent more food than is produced today (Godfray 2010; FAO 2009). On one hand unpredicted changes in climatic parameters are likely to threaten the production and productivity of economically important plant species particularly that of food crops, at the same time agriculture productivity requires significant increase to meet the expected growth in demand for food by the ever increasing world population in the next few decades. The impact of climate variability and climate change on agricultural productivity is likely to be a major constraint to achieving targeted levels of food production. This makes the development of crop genotypes with resilience to climate change an important strategy for food security. Crop diversity is essential for achieving food security under changing climate scenario. Farmers have always relied on crop genetic diversity to mitigate the effects of variability in climatic situations. Plant genetic resources are the raw material for breeding the next generation of crops to respond to the biotic and abiotic stresses brought by climate change. Efforts have been made since long to collect, conserve and evaluate plant genetic resources (PGRs), to support the plant breeders with diverse genetic materials, to widen the genetic base and to create new crop varieties to combat the climate change (Bansal et al., 2014). Although there are 240000 species of plants estimated to grow on earth, yet only 
25-30 of them are used for human consumption, and of these, rice, wheat and maize together constitute about 75 per cent of global grain production (Cordain, 1999). Therefore, conservation, multiplication and sustainable utilization of the existing PGRs, which comprise cultivars, landraces and wild relatives, are essential to combat not only the food shortage but also for mitigating the crop loss due to climate change. To meet the challenges of climate change, exploring and conserving natural diversity in the existing plant genetic resource pool is needed for developing climate-resilient elite genotypes.

Plant genetic resources, a major component of agricultural biodiversity, play a key role in improving agricultural production and productivity. The enhanced use of agricultural biodiversity will play an essential role in providing improved adaptability and resilience in agro-ecosystems. Given their potential to coping with climate change, the sustainable management of plant genetic resources for food and agriculture should be a basic component of strategies dealing with climate change adaptation in the rural sectors. Improved use of plant genetic resources will be essential, and this is likely to require increased national and international movements of resources to ensure that adapted germplasm is available to meet changing production environments. Greater emphasis will ahve to be placed on evaluation for resistance to biotic and abiotic stresses and on properties such as adaptability, plasticity, and resilience, which can help maintain productivity under changing environmental conditions. Despite the advancements in modern technologies, research strategies for developing climate-resilient cultivars are scanty. An integrated strategy based on molecular breeding and genetic engineering approaches utilizing the PGRs is gaining momentum (Varshney et al. 2011). Thus, there is an urgent need to accelerate research efforts to harness the genetic potential of PGRs in general and specifically the wild or alien gene pool by prebreeding and by modern genomics approaches to develop superior stress-tolerant cultivars.

\section{Strategies for conservation of plant genetic resources in view of climate change}

As a result of climate change, increased efforts will be needed to conserve the diversity of crops and their wild relatives. Both in situ and ex situ conservation strategies will have to be adapted to secure biodiversity threatened by changing climate and altered production practices. Recently the conservation of PGR and TK of germplasm has taken a centre stage in mitigating the varied effects of climate change on agriculture and allied sectors. The importance of biodiversity conservation as a crucial international issue has greatly increased since the signing of the Convention on Biological Diversity (CBD) in Rio de Janeiro in 1992. The CBD highlights three objectives: i) conservation of biological diversity, ii) sustainable use of its components, and iii) equitable sharing of benefits arising from the use of genetic resources. Therefore, to meet the demand for food scarcity worldwide and to address human health concerns, the effective and time bound measures must be carried out for conserving the diversity of PGR and TK of germplasm to ensure its continued availability. To keep all these parameters in the mind, following are the different approaches towards conserving the PGR and TK of germplasm:

(a) In situ conservation

(b) Ex situ conservation

(c) Biotechnological approaches

\section{(a) In situ conservation}

In situ conservation of biological resources refers to their maintenance in the natural habitats where they occur, whether as uncultivated plant communities or in farmers' fields. The authoritative legal definition of in situ conservation is found in the United Nations Convention on Biological Diversity (CBD) which is read as "the conservation of ecosystems and natural habitats and the maintenance and recovery of viable populations of species in their natural surroundings and, in the case of domesticated or cultivated species, in the surroundings where they have developed their distinctive properties." As the Convention states, the species may be wild or domesticated (cultivated) and the habitats may be natural ecosystems or agro-ecosystems. In situ conservation of cultivated species is primarily concerned with the on-farm maintenance of traditional crop varieties (or landraces) and with forage and agroforestry species. Active 
participation by farmers and other users of genetic resources is an important part of in situ conservation of cultivated species. The CBD explicitly promotes in situ conservation, through the establishment of protected areas and natural parks (Scarascia-Mugnozza et al., 2002).

In this approach, plant species are promoted to grow in their natural habitats i.e., wilderness areas, reserves, protected areas and within traditional farming systems where evolutionary processes continue to operate (Ogbu 2010). This type of conservation efforts have several advantages that includes conserving a large range of potentially interesting alleles, enhance and ensure sustainable use of genetic variation for present and future human needs, assures protection of associated species and facilitates research on species in their natural habitats, thus allow a better evaluation and utilization. This method of conservation is of great significance to the wild relatives of crop plants especially tree crops and forest species where there are limitations on the effectiveness of ex situ methods of conservation. The novel genetic resources may be conserved even in home gardens (Rathore et al. 2005; Tao 2003). The drawback of the methodology are time consuming process, cost, size, cover only very small portion of total diversity of a crop species, political and social issues, and the danger of genetic wipe out as a result of natural disasters.

In situ conservation is very difficult to carry out due to the limitations such as an adequate sample has to be taken for the conservation of genetic diversity, more space requirement, expensive, requires trained personnel, cumbersome to manage and are vulnerable to natural vagaries (genetic erosion). Researchers across the globe have tried to prevent the illegal and over harvesting of important medicinal plants by introducing a concept of plant part or plant species substitution to satiate the need of the industry. In South Africa, in response to the serious scarcity of Ocotea bullata (Burch.), an important medicinal plant, Cryptocarya species (Lauraceae) are frequently used as substitute plant (Zschocke and Van 2000). Using the methods to substitute the plant or its part is a promising approach to fulfil the scarcity of the medicinally important compound but the fate of the plant still remains a question.

\section{(b) Ex situ conservation}

The process of cultivating the overexploited and endangered medicinal plants outside their natural habitat due to its habitat degradation and destruction has become an alternative approach for conservation. e.g. Paris species in family Trilliaceae and Panax species in family Araliaceae (Long et al. 2003). It provides the opportunity to study the biology for research purposes and to understand the threats to endangered species, to supply plant materials for propagation, for re-introduction, for agronomic improvement, and for education purposes (Temitope 2013). The importance of ex situ conservation has gained international recognition with its inclusion in Article 9 of the Convention on Biological Diversity (CBD) and in Target 8 of the Global Strategy for Plant Conservation (www.bgci.org.uk/files/7/0/global_strategy.pdf).

The notable disadvantage is that the sample of the species conserved ex situ may represent a narrower range of genetic variation than that which occurs in the wild. It involves three methods to conserve namely seed storage in seed banks, field gene banks and botanical gardens (Withers and Engelmann 1998).

\section{(c) Biotechnological approaches}

Biotechnology plays an important role in international plant conservation programs and in preservation of the PGR (Bajaj, 1995; Benson, 1999; Ramanatha and Riley, 1994; Withers, 1995) and it impacts various aspects and economic progress of various nations around the world. The cell fusion techniques, recombinant DNA technology, protein engineering, structural biology and micropropagation methods have made phenomenal progress as priority research areas and generating high quality and genetically superior planting materials. When the biological material (organs, seeds, buds, etc.) cannot be stored in a traditional/classical manner due to reproductive problem and / or extremely reduced population, biotechnological approaches are becoming increasingly important in the conservation of endangered/threatened plants and can play an important role in ex situ conservation efforts. Advances in plant biotechnology, especially those associated to in vitro culture, cryopreservation and molecular biology; provide new methods for PGR and evaluation (Paunesca, 2009). Biotechnological tools are largely used for both planted and naturally regenerated forests (Sonnino et. al, 2015) 
Biotechnologies can be used in production systems, based on agroecological principles, to enhance productivity while ensuring sustainability, conservation of genetic resources and use of indigenous knowledge FAO (2016). At present, the following biotechnological methods have been used to rapid multiply and conserve endangered, rare, crop, ornamental, medicinal and forest species, allowing the conservation of pathogen-free material, elite plants and genetic diversity for short-, medium- and long-term. These include:

(i) In vitro propagation

(ii) Mycorrhization

(iii) Genetic transformation

(iv) DNA banks

(v) Cryopreservation

In vitro propagation

In vitro propagation is used for the production and multiplication (micropropagation) of large number of plants throughout the year irrespective of the season. The callus production from explants such as leaves, seeds, nodes, tubers etc. followed by shoots and roots, or from auxillary explant followed by rooting, finally leads to the development of whole plantelet under controlled conditions, which after acclimatization can be transferred in the field (Rai 2010). Using this method stock of pathogen free germplasm can be raised and maintained economically for many years.

Explants used for in vitro conservation must be of right type as well as of physiological stage. For species producing orthodox seeds, the most common way to acquire plant material is through seed collection, and if absence or inadequate seed development hinder seed collection, then zygotic embryos or vegetative tissues, like budwoods, shoots apices or leaves, tubers or corms can be collected. The apical and auxiliary meristems of very small size are the preferred explants for in vitro storage. In fact, organized explants have proved better than unorganized tissues, in terms of genetic stability of the germplasm (Mandal 2003; Chaudhury and Vasil 1993; Kameswara 2004; Ogbu 2010). The advantages associated with in vitro propagation include clonal propagation, production of insect and disease free material, zero genetic erosion, requires short time for obtaining new plants, less space and less labour intensive, allows safe mean to internationally exchange plant material and lead to genetic modifications like somaclonal variations (stress factor resistance, production of useful compounds, etc.).

Regeneration and successful propagation of genetically stable seedlings from cultures are prerequisites for any in vitro conservation effort. Generally, organized cultures such as shoots are used for slow growth storage since undifferentiated tissues such as callus are more vulnerable to somaclonal variation. Slow growth techniques have been developed for medium-term conservation of crop species (Engelmann and Drew 1998; Sarkar and Naik 1998 and Ogbu 2010) in which germplasm accessions are kept as sterile plant tissues or plantlets on nutrient gels and to be held for 1-15 years under tissue culture conditions with periodic sub-culturing, depending on species. There are several methods by which slow growth can be maintained in most cases, a low temperature often in combination with low light intensity or even darkness is used. Temperatures in the range of $0-5^{\circ} \mathrm{C}$ are employed with cold tolerant species, but for tropical species which are generally sensitive to cold, temperatures between $15^{\circ} \mathrm{C}$ and $20^{\circ} \mathrm{C}$ are used. It is also possible to limit growth by modifying the culture medium, use of growth retardants, by reducing the sugar and/or mineral elements concentration and reduction of oxygen level available to cultures by covering explants with a layer of liquid medium or mineral oil (Withers, 1997). Although slow growth procedures have been developed for a wide range of species, they are routinely used for conservation of genetic resources of only a few species including Musa spp., potato, sweet potato, cassava, yam, Allium spp. and temperate tree species.

The first in vitro collecting systems were developed for cocoa (Theobroma cacao L.) and coconut (Cocos nucifera L.), generating two in vitro collecting methods that act as a model to develop other protocols (Withers 2002). Rai (2010), cited a list of plants under possible endangered stage and stated that in vitro culturing of endangered plants like Aquilaria malaccensis, Dioscorea deltoidea, Guaicum officinale, Hydrastis canadensis, Nardostachys grandiflora, Panax quinquefolius, Picrorhiza kurroa, Podophyllum hexandrum, Buchanania lanzan, Prunus africana, Pterocarpus 
santalinus, Rauwolfia serpentina, Saussurea costus, Gloriosa superb and Taxus wallichiana will be beneficial because these plants will reach 'critically endangered', or 'possibly endangered' stage. Out of these endangered species such as Gloriosa superba L, Rauwolfia serpentina L. Benth. Ex. Kurz. and Buchanania lanzan Spreng have been successfully conserved through in vitro propagation (Rai 2010).

\section{Mycorrhization}

A process in which the inoculation of mycorrhizal fungi is done into the roots of plants is referred as mycorrhization. These fungi make symbiotic relationship with 90 per cent of the plants (Williams et al. 1994) and helps in the uptake of nutrients particularly phosphorus from the soil sytem (Vestberg and Estaun, 1994). For better survival and sustainable plant production, mycorrhization of the micropropagated plantlets is necessary. In vitro co-culture of beneficial microbes with tissue culture raised plantlets of endangered medicinal plants during the acclimatization process induced developmental and metabolic changes which help to enhance their tolerance to various stresses.

\section{Gene transformation}

Agrobacterium tumifaciens and Agrobacterium rhizogenes are the potent biological tools for transformation of endangered medicinal plants for development of varieties resistant to stress conditions and also for over production of secondary metabolites in hormone free culture conditions so that exploitation of these plants will be minimized. Genetic transformation facilitates the growth of medicinal plants with multiple durable resistances to pests and diseases. Likewise, transgenes or marker-assisted selection may assist in the development of insect, pest, and drought, salinity resistant plants, which will be needed to fulfil the world's need and save land for the conservation of plant biodiversity in natural habitats. There are more than 120 species belonging to 35 families in which transformation has been carried out successfully by using Agrobacterium and other transformations techniques (Birch 1997).

\section{DNA banks}

DNA banks maintain a library of the "DNA sample" in a way much similar to the "Gene Library" which provides vital information to the worldwide scientists for the conservation of PGR. It may be conservation of genome fragments or individual genes or entire genotypes for their future use. For many species that are difficult to conserve by conventional means (either as seeds or vegetative) or that are highly threatened in the wild, DNA storage may provide the ultimate way to conserve the genetic diversity of these species and their populations in the short-term, until effective methods can be developed (Dulloo et al., 2006). The extraction of genetic material and storage should be made readily available for molecular applications. DNA resources can be maintained at $-20^{\circ} \mathrm{C}$ for short and midterm storage up to 2 years and at $-70^{\circ} \mathrm{C}$ or in liquid nitrogen for longer periods.

A number of DNA banks are present worldwide which include those managed by the International Rice Research Institute, South African National Biodiversity Institute, and National Institute of Agrobiological Sciences in Japan. Gene bank documentation has been enhanced with the advances in information technology, geographical information systems (GIS), and DNA marker technology. Information on DNA assessment of variation derived through these technologies help search for important genes (Ortiz, 2002). Information from DNA collections is available online through biodiversity initiatives such as Global Biodiversity Information (www.gbif.net), Species 2000 (www.species2000.org), and Inter-American Biodiversity Network (www.ukbiodiversity.net) (Hodkinson et al., 2007)

Some important DNA banks which spread across the globe are:

(i) The Royal Botanic Garden, Kew, UK, presently the world's largest and the most comprehensive PGR DNA bank, consisting of over 20,000 DNA specimens representative of all plant families.

(ii) The US Missouri Botanical Garden has collection of more than 20,000 plant tissue samples, and provide raw material for the extraction of DNA for its subsequent use in conservation research.

(iii) The Australian Plant DNA Bank of Southern Cross University has representative genetic information from the entire Australian flora.

(iv) Leslie Hill Molecular Systematics Laboratory of the National Botanical Institute (NBI) in collaboration with the Royal Botanic Garden, Kew, preserves genetic material of the South African flora (Rice et al. 2006). 


\section{Cryopreservation}

Biotechnology plays a very important role short-term preservation of germplasm, and offers the possibility of preserving the propagated material in the medium-term (cold storage) or long-term using cryopreservation (Corredoira, 2017). Cryopreservation refers to the non lethal storage of biological tissues at ultra low temperature, usually that of liquid nitrogen $(\mathrm{LN})$ which is $-196^{\circ} \mathrm{C}$. Due to storage at the temperature of the vapor phase $\left(-150\right.$ to $\left.-180^{\circ} \mathrm{C}\right)$ or liquid phase $\left(-196^{\circ} \mathrm{C}\right)$ of $\mathrm{LN}$, cell divisions and all kinds of biological metabolism are arrested and thus, plant material can be stored for unlimited periods of time. It is the only option available for the long-term conservation of germplasm of vegetatively propagated and recalcitrant seed species. These method donot require subculture steps for long tissue culture storage and reduced level of somaclonal variation observed (Martin et al., 1998). In cryopreservation, shoot apices or meristems cultures are suitable because of virus-free plant production, clonal propagation, easier recovery and less mutation (Scowcroft, 1984). It offers a good method for conservation of the species, especially woody plant germplasm (Panis, 2005).

Conservation of germplasm using cryogenic approach required very limited space. The plant material stored is protected from exogenous contamination and needs very limited maintenance. It causes no change in viability, vigor and genetic makeup of the conserved materials (Ogbu, 2010). For long-term preservation of species producing recalcitrant seeds, excised zygotic embryo cultures are consider good for cryopreservation which has been successfully employed for the cryopreservation of coconut (Assy-Bah and Engelmann, 1992 ), cocoa (Chandel et al., 1995), walnut (De Boucaud et al., 1991), jack fruit (Chandel et al., 1995), and neem (Berjak and Dumet, 1996).

Cryopreservation technique works on the basis of removal of all freezable water from tissues by physical or osmotic dehydration, followed by ultra-rapid freezing (Kaviani, 2011). The various techniques currently in use include classical and new cryopreservation techniques (Kameswara, 2004; Withers, 1998). Classical techniques involve freeze-induced dehydration, whereas new techniques are based on vitrification. Vitrification can be defined as the transition of water directly from the liquid phase into an amorphous phase or glass, whilst avoiding the formation of crystalline ice (Fahy et al., 1984).

Classical technique of freezing procedures involved the following successive steps: pre-growth of samples, cryoprotection, slow cooling $\left(0.5-2.0^{\circ} \mathrm{C} / \mathrm{min}\right)$ to a determined pre-freezing temperature (usually around $\left.-40^{\circ} \mathrm{C}\right)$, rapid immersion of samples in liquid nitrogen, storage, rapid thawing and recovery. Cryoprotectants are added to the freezing mixtures to maintain membrane integrity and increase osmotic potential of the external medium. This approach required sophisticated and expensive programmable freezers which are not recommendable for cryopreservation.

In vitrification based procedures, cell dehydration is performed prior to freezing by exposure of samples to concentrated cryoprotective media and/or air desiccation. This is followed by rapid cooling. As a result, all factors that affect intracellular ice formation are avoided. Vitrification based procedures offer practical advantages in comparison to classical freezing techniques. Like ultra-rapid freezing, they are more appropriate for complex organs (shoot tips, embryos), which contain a variety of cell types, each with unique requirements under conditions of freeze-induced dehydration.

By precluding ice formation in the system, vitrification based procedures are operationally less complex than classical ones as they do not require the use of controlled freezers and have greater potential for broad applicability, requiring only minor modifications for different cell types (Engelmann 1997). Engelmann (2000) described seven vitrification based procedures in use for cryopreservation, which include:

\section{i) Pregrowth}

The pregrowth technique consists of cultivating samples in the presence of cryoprotectants and then freezing them rapidly by direct immersion in liquid nitrogen. The pre-growth technique has been developed for Musa meristematic cultures (Panis, 2007).

\section{ii) Dehydration}

Dehydration is the simplest vitrification based procedures which require dehydrating explants and then freezing 
them rapidly by direct immersion in liquid nitrogen. This technique is mainly used with zygotic embryos or embryonic axes extracted from seeds. It has been applied to embryos of a large number of recalcitrant and intermediate species (Engelmann, 2000). Desiccation is usually performed in the air current of a laminar airflow cabinet, but more precise and reproducible dehydration conditions are achieved by using a flow of sterile compressed air or silica gel. Ultra-rapid drying in a stream of compressed dry air allows freezing samples with relatively higher water content, thus reducing desiccation injury. However, optimal survival is generally obtained when samples are frozen with water contents between 10 and $20 \%$ (fresh weight basis).

\section{iii) Pre-growth dehydration}

The pre-growth dehydration procedure involves pregrowth of explants in the presence of cryoprotectants, dehydration under the laminar airflow cabinet or with silica gel and then rapid freezing. This method has been applied notably to asparagus stem segments, oil palm polyembryonic cultures and coconut zygotic embryos (Uragami et al., 1990; Dumet et al., 1993).

\section{iv) Encapsulation dehydration}

Cryopreservation using the encapsulation dehydration procedure has been very effective for freezing apices of different plant species from temperate and tropical origin (Gonzalez-Arnao and Engelmann, 2006). The protocol comprises encapsulation, preculture of alginate coated samples in liquid medium with high sucrose concentration, desiccation, rapid cooling and slow rewarming. It is important to note that after such a drastic drying process (desiccation down to around 25 per cent moisture content in alginate beads,) survival of explants after thawing may become independent of the warming rate, as noted for example with carrot somatic embryos (Dereuddre et al., 1991) and orchid seeds with fungal symbiont (Wood et al., 2000). For recovery, encapsulated samples are generally placed on standard culture medium without having to extract the explants from their alginate coating (Gonzalez-Arnao and Engelmann, 2006). Mandal et al. (2009) cryopreserved embryogenic cultures of Dioscorea bulbifera using this procedure and reported 53.3 per cent recovery of growth of embryogenic culture after cryopreservation.

v) Vitrification

The freezing procedure referred to as vitrification comprises a pretreatment (loading treatment) at room temperature, followed by exposure to a vitrification solution at $25^{\circ}$ or $0^{\circ} \mathrm{C}$, rapid cooling and warming, and final removal of the vitrification solution by washing samples with an unloading solution consisting of liquid culture medium supplemented with 1.2 M sucrose (Withers and Engelmann, 1998).

\section{vi) Encapsulation vitrification}

Encapsulation vitrification is a combination of the encapsulation-dehydration and vitrification procedures, where samples are encapsulated in alginate beads, and then subjected to freezing following the vitrification approach.

\section{vii) Droplet vitrification}

The droplet vitrification technique is characterized by increased cooling and warming rates compared to other vitrification-based procedures, since samples are frozen in minute droplets of PVS placed on aluminium foil strips, which are plunged directly in liquid nitrogen. This protocol significantly increases the probability of obtaining a vitrified state during freezing, and of avoiding devitrification during warming (Panis and Lambardi, 2005).

The establishment of National cryobank at National Bureau of Plant Genetic Resources (NBPGR), New Delhi has responsibility to conserve desiccation sensitive seeds, vegetative tissues, pollen and selected orthodox seed species. Presently about 6 large capacity cryotanks capable of accommodating 30,000 to 40,000 samples of varied germplasm in the form of seeds, embryo, embryonic axes, shoot apices and pollen are available.

\section{Conclusion}

Conservation and sustainable use of attentive plant genetic resources and traditional knowledge of germplasm is essential so that we can meet the demand for future food security. Advances in biotechnology, especially in the areas of in vitro culture techniques, cryoperservation and molecular biology have generated new opportunities for improved 
conservation, utilization and management of plant genetic resources. Biodiversity is considered the basis for sustaining the life on the planet, playing an important role as bioeconomy. It has been predicted that the $21^{\text {st }}$ century would be an era of bio-economy driven by advances in bioscience and biotechnology. Bio-economy may become the fourth economy after agricultural, industrial, and information technology, having far reaching impacts on sustainable development in agriculture, forestry, environmental protection, light industry, food supply and health care and other micro-economy aspects. Besides these attempts, it would be better for the involvement of local communities in biodiversity conservation program to make it profitable. To achieve this, an ecotourism attempt to promote sustainable, low impact tourism to protected areas as a way of generating income for local communities should be developed for economic incentives for the conservation of natural ecosystems. Thus, a strategic and forward vision for conservation of plant genetic resources and traditional knowledge of germplasm and sustainable use of plant resources in the $21^{\text {st }}$ century is of far reaching significance for sustainable development.

\section{Conflict of Interest}

No conflict of interest was reported by the authors.

\section{References}

1. Alves RR, Rosa IL. Biodiversity, traditional medicine and public health: where do they meet? J Ethnobiol Ethnomed 2007; 3: 1-9.

2. Assy-Bah B, Engelmann F. Cryopreservation of mature embryos of coconut (Coccos nucifera L.) and subsequent regeneration of plantlets. Cryo Lett 1992; 13: 117- 126.

3. Bajaj YPS. Cryopreservation of plant cell, tissue and organ culture for the conservation of germplasm and biodiversity. In: Bajaj YPS (ed) Biotechnology in agriculture and forestry cryopreservation of plant germplasm I, New York, Springer-Verlage, 1995; p3-18.

4. Benson EE. Cryopreservation. In: Benson EE (ed) Plant conservation biotechnology, Taylor and Francis, London, 1999; p83-95.

5. Berjak P, Dumet D. Cryopreservation of seeds and isolated embryonic axes of neem (Azadirachta indica). Cryo Lett 1996; 17: 99-104.

6. Birch RG. Plant transformation: Problems and strategies for practical application. Annu Rev Plant Physiol Plant Mol Biol 1997; 48: 297-326.

7. CBD United Nations Convention on Biological Diversity. Preamble. https://www.cbd.int/doc/legal/cbd-en.pdf 1992.

8. Chandel KPS, Chaudhury R, Radhamani J, et al. Desiccation and freezing sensitivity in recalcitrant seeds of tea,cocoa and jackfruit. Ann Bot 1995; 76: 443-450.

9. Chaudhury MKU, Vasil IK. Molecular analysis of plant regenerated from embryogenic cultures of apple. Genet 1993; 86: 181-188.

10. Corredoira E, Teresa MM, José Cernadas M, et al. Application of Biotechnology in the Conservation of the Genus Castanea. Forests 2017; 8: 394. doi:10.3390/f8100394

11. Das JS. The largest genetic paradise of India lacks biotechnological implementation. Cur 2008. Sci 94: 558-559.

12. De Boucaud M, Brison M, Ledoux C, et al. Cryoperservation of embryonic axes of recalcitrant seed: Juglans regia L. cv Franquette. Cryo Lett 1991; 12: 163-166.

13. Dereuddre J, Blandin S, Hassen N. Resistance of alginate-coated somatic embryos of carrot (Daucus carota L.) to desiccation and freezing in liquid nitrogen: effects of preculture. Cryo Lett 1991; 12: 125-134.

14. Dhillon BS, Saxena S. Conservation and Access to Plant Genetic Resources. In: Mandal BB, Chaudhury R, Engelmann F, Mal B, Tao KL, Dhillon BS (eds) Conservation Biotechnology of Plant Germplasm. NBPGR, New Delhi/IPGRI, Rome/FAO, Rome, 2003; p3-18

15. Drummond RS, Keeling DJ, Richardson TE, et al. Genetic analysis and conservation of 31 surviving individuals of a rare New Zealand tree, Metrosideros bartlettii (Myrtaceae). Mol Ecol 2000; 9: 1149-1157.

16. Dulloo E, Nagamura Y, Ryder O. DNA storage as a complementary conservation strategy. In: Vicente MC de, Andersson MS (eds) DNA banks-providing novel options for gene banks? Topical reviews in agricultural biodiversity. International Plant Genetic Resources Institute, Rome, Italy2006.

17. Dumet D, Engelmann F, Chabrillange N, et al. Cryopreservation of oil palm (Elaeis guinensis Jacq.) somatic embryos involving a desiccation step. Plant Cell Rep 1993; 12: 352-355.

18. Engelmann F. In vitro conservation methods. In: Ford-Lloyd BV, Newburry JH, Callow JA (eds) Biotechnology and plant genetic resources: conservation and use. CABI, Wellingford, 1997; p119-162.

19. Engelmann F. Importance of cryopreservation for the conservation of plant genetic resources. In: Engelmann F, Takagi H (eds) Cryopreservation of tropical plant germplasm. Current research progress and application. IPGRI, Rome, Italy, 2000; p8-20.

20. Engelmann F, Drew RA. In vitro germplasm conservation. Acta Hortic 461: 41-47.

21. Engels J, Visser B. Genebank Management: Effective management of germplasm collection. Training manual on 
“Conservation, Management and use of Plant Genetic resources in food and Agriculture”. Wageningen University and Research, Wageningen, the Netherlands 2006.

22. Fahy GM, MacFarlane DR, Angell CA, et al. Vitrification as an approach to cryopreservation. Cryobiol 1984; 21 : 407-426.

23. Falk BW, Purciful DE. Development and application of an enzyme-linked Immunosorbent assay (ELISA) test to index lettuce seeds for lettuce mosaic virus in Florida. Plant Dis 1983; 67: 413-416.

24. FAO. International Undertaking on Plant Genetic Resources for Food and Agriculture. Food and Agriculture Organisation. Commission on Genetic Rsources for Food and Agriculture 1983.

http://www.fao.org/Ag/cgrfa/iu.htm

25. FAO. State of World's Plant Genetic Resources for Food and Agriculture. FAO, Rome Italy,1996.

26. FAO. International Symposium on The role of agricultural biotechnologies in sustainable food systems and nutrition, Rome, 2016; 15-17 February. Proceedings.

27. Gitzendanner MA, Soltis S. Patterns of genetic variation in rare and widespread plant congeners. Am J Bot 2000; 87: 783-792.

28. Gonzalez-Arnao MT, Engelmann F. Cryopreservation of plant germplasm using the encapsulation-dehydration technique: review and case study on sugarcane. Cryo Lett 2006; 27: 155-168.

29. Groombridge B, Jenkins MD. Global Biodiversity : Earth's living resources in the 21 st century, World Conservation Monitoring Centre, UK, 2000.

30. Hamrick JL, Godt MJW. Allozyme diversity in plant species. In: Brown AHD, Clegg, Kahler MT, Weirn AL (eds) Plant Population Genetics, Breeding and Genetic Resources, Sinauer, Sunderland, 1989; p43-63.

31. Hodgson RAJ, Randles JW. Diagnostic Oligonucleotide-Probe (DOP) hybridization to detect coconut cadang-cadang viroid In Viroid-like Sequences of Coconut. In: Diekmann, M (ed) Kuala Lumpur, Malaysia. ACIAR and IPGRI, Canberra and Rome 1997.

32. Hodkinson TR, Waldren S, Parnell J, et al. DNA Banking for Plant Breeding, Biotechnology and Biodiversity Evaluation. Plant Res 2007; 120:17-29.

33. Huang HW, Layne DR, Kubisiak TL. RAPD inheritance and diversity in pawpaw (Asimina triloba). J Am Soc Hort Sci 2000; 125: 454 - 459.

34. Jimu L. Threats and conservation strategies for the African cherry (Prunus africana) in its natural range- A review. Ecol Natural Environ 2011; 3: 118-130.

35. Kameswara RN. Plant genetic resources: Advancing conservation and use through biotechnology. Afr J Biotechnol 2004; 3: 136-145.

36. Karp A, Seberg O, Buiatti M. Molecular Techniques in the Assessment of Botanical Diversity. Ann Bot 1996; 78:143-149.

37. Karp A. The new genetic era: will it help us in managing genetic diversity? In: Engels JMM, Ramanatha RV, Brown AHD, Jackson MT (eds) Managing Plant Genetic Diversity. Wallingford and Rome, CAB International and IPGRI, 2002; p43-56.

38. Kasagana VN, Karumuri, SS. Conservation Of Medicinal Plants (Past, Present \&amp; Future Trends). J Pharm Sci Res 2011; 3: 1378-1386.

39. Kaviani B. Conservation of plant genetic resources by cryopreservation. Aus J Cro Sci 5: 2011; 778-800.

40. Leisa. Valuing Crop Diversity. LEISA Magazine 2004; 20: 4-5.

41. Long CL, Li H, Ouyang ZQ, Yang XY, Li Q, Trangmar B (2003) Strategies for agrobiodiversity conservation and promotion: a case from Yunnan, China. Biodivers Conserv 12: 1145-1156.

42. Mandal BB. Cryopreservation Techniques for plant germplasm conservation. In: Mandal BB, Chasdhury R, Engelmann F, Mal B, Tao KL, Dhillen BS (eds) Conservation biotechnology of Plant Germplasm 2003.

43. Mandal BB, Dixit SS, Srivastava PS. Cryopreservation of embryogenic cultures of Dioscorea bulbifera L. by encapsulation-dehydration. Cryo Lett 2009; 30: 440-448.

44. Martin C, Iridono JM, Benito-Gonzales E, et al. The use of tissue culture techniques in the conservation of plant biodiversity. Agro Food Ind Hi Tech 1998; 9: 37-40.

45. Meloni M, Perini D, Filigheddu R, et al. Genetic Variation in Five Mediterranean Populations of Juniperus phoenicea as Revealed by Inter-Simple Sequence Repeat (ISSR) Markers. Ann Bot 2006; 97: 299-304.

46. Minsavage GV, Hoover RJ, Kucharek TA, et al. Detection of the watermelom fruit blotch pathogen on seeds with the polymerase chain reaction. Phytopathology 1995; 85: 1162.

47. Myers N, Mittermeier RA, Mittermeier CG, et al. Biodiversity hotspots for conservation priorties. Nature 2000; 403: 853-858.

48. Nebauer SG, Castillo-Agudo L, Segura J. RAPD variation within and among natural populations of outcrossing willow-leaved foxglove (Digitalis obscura L.) Theor Appl Genet 1999; 98: 985-994.

49. Nybom H. Comparison of different nuclear DNA markers for estimating intraspecific genetic diversity in plants. Mol Ecol 2004; 13: 1143-1155. 
50. Nybom H, Bartish IV. Effects of life history traits and sampling strategies on genetic diversity estimates obtained with RAPD markers in plants. Perspect Plant Ecol Evol Syst 2000; 3: 93-114.

51. Ogbu JU, Essien BA, Essien JB, et al. Conservation and management of genetic resources of horticultural crops in Nigeria: Issues and biotechnological strategies. J Hortic For 2010; 2: 214-222.

52. Ortiz R. Not Just Seed Repositories: A More Proactive Role for Gene Banks. 2002.

53. Pandey G. Some important anticancer Herbs: A Review. Int J Pharm Stud Res 2011; 2: 32-38.

54. Panis B. Fundamental aspects of plant cryopreservation. Training Manual on In vitro and Cryopreservation Techniques for conservation of PGR. NBPGR and Biodiversity International, New Delhi, 2007.

55. Panis B, Lambardi M. Status of cryopreservation technologies in plants (crops and forest trees). The role of biotechnology. Villa Gualino, Turin, Italy, 2005; p43-54.

56. Paunesca A. Biotechnology for endangered plant conservation: A critical overview. Romanian Biotech Letters 2009; 14: 4095-4104.

57. Rai MK. Review: Biotechnological strategies for conservation of rare and endangered medicinal plants. Biodicersitas 2010; 11: 157-166.

58. Ramanatha RV, Riley R. The use of biotechnology for conservation and utilization of plant genetic resources. Plant Genet Resour Newsl 1994; 97: 3-20.

59. Rao NK. Plant genetic resources: Advancing conservation and use through biotechnology. African J Biotech 2004; 3: $136-145$.

60. Rathore DS, Srivastava U, Dhillon BS. Management of Genetic Resources of Horticultural Crops: Issues and Strategies. In: Dhillon BS, Tyagi RK, Saxena S and Randhawa GJ (eds) Plant genetic Resources: Horticultural crops. Narosa Publishing House, New Delhi, 2005; p1-18.

61. Rice NR, Henry M, Rossetto. DNA banks: a primary resource for conservation research. In: MC de Vicente (ed) DNA banks - providing novel options for Genebanks? Topical Reviews in Agricultural Biodiversity, International Plant Genetic Resources Institute, Rome, Italy, 2006; p41-48.

62. Roberts EH. Predicting the storage life of seeds. Seed Sci and Technol 1973; 1: 499-514.

63. Rodgers WA, Panwar HS, Mathur VB. Wildlife Protected Areas in India: A review (Executive Summary). Wildlife Institute of India, Dehradun, 2002; p44.

64. Santos SM, Cruz L. A rapid and sensitive detection of Clavibacter michiganensis subsp. michiganensis in tomato seed by polymerase chain reaction. Seed Sci Technol 1997; 25: 581-584.

65. Sarkar D, Naik PS. Factors effecting minimal growth conservation of potato microplant in vitro. Euphytica 1999; 102: $275-280$.

66. Scarascia-Mugnozza, GTand Perrino, P. The history of ex situ conservation and use of plant genetic resources. In: Managing Plant Genetic Diversity (Engels, V., Ramanatha, R., Brown, A., Jackson, M.T., Eds.), CABI Publishing: New York, NY, USA; 2002; p1-22.

67. Schaad NW, Cheong SS, Tamaki S, et al. A combined biological and enzymatic amplification (BIO-PCR) technique to detect Pseudomonos syringe pv phaseolicola in bean seed extracts. Phytopathol 1995; 85: 243-248.

68. Scowcroft WR. Genetic variability in tissue culture: Impact on germplasm conservation and utilization. International Board for Plant Genetic Resources Secretariat, Rome, 1984; p42.

69. Sharma SK. Indian Plant Genetic Resources (PGR) System: Role of NBPGR. Training manual on In vitro and Cryopreservation Techniques for conservation of PGR. NBPGR and Bioversity International, New Delhi, India, 2007.

70. Sharma KD, Brij Singh BM, Sharma TR, et al. Molecular analysis of variability in Podophyllum hexandrum Royle - an endangered medicinal herb of northwestern Himalaya. Plant Genet Resour Newsl 2000; 124: $57-61$.

71. Sica M, Gamba G, Montieri S, et al. ISSR markers show differentiation among Italian populations of Asparagus acutifolius L. BMC Genet, 2005; 6:17

72. Singh RB. Biotechnology, Biodiversity, and Sustainable Agriculture: A Contradiction. 2000.

73. Sonnino, A. Current status of biotechnology development and application in forestry. In Proceedings of the International Symposium on Forest Biotechnology for Smallholders, Foz do Iguaçu, Paraná, Brazil, 19-22 May 2015; FAO: Rome, Italy, 2015.

74. Sonnino, A. International Instruments for Conservation and Sustainable Use of Plant Genetic Resources for Food and Agriculture: An Historical Appraisal. Diversity, 2017; 9: 2-19.

75. Swanson T, Pearce D, Cervigni R. The appropriation of the value of Plant genetic resources for Agriculture, Commission for Plant genetic resources: Washington DC, 1994.

76. Tandon P, Kumaria S. Prospects of Plant Conservation Biotechnology in India with Special Reference to Northeastern Region. In: Tandon P, Kumaria S, (eds) Biodiversity: Status and Prospects. 2005.

77. Tao KL. Complementary Conservation Strategy for Plant Genetic resources. In: Mandal BB, Chaudhury R, Engelmann F, Mal B, Tao KL and Dhillon BS (eds) Conservation Biotechnology of Plant Germplasm. NBPGR, New Delhi/IPGRI, Rome/FAO, Rome, 2003; p51. 
78. Taylor JL. A simple, sensitive and rapis method for detecting seed contaminated with highly virulent Leptosphaeria maculans. Appl Env Microbiol 1953; 59: 3681-3685.

79. Temitope IB. The state of ex-situ conservation in Nigeria Int J Conserv Sci 2013; 4: 197-212.

80. Uragami A, Sakai A, Nagai M. Cryopreservation of dried axillary buds from plantlets of Asparagus officinalis L. grown in vitro. Plant cell rep 1990; 9: 328-331.

81. Vestberg M, Estaun V. Micropropagated plants, an opportunity to positively manage mycorrhizal activities. In: Gianinazzi S, Schuepp H (eds.) Impact of arbuscular mycorrhizas on sustainable agriculture and natural ecosystems. Birkhauser, Basel. 1994.

82. Vickers A, Zollman C. Herbal medicine. BMJ 1999; 319: 1050-1053.

83. Williams PG, Roser DJ, Seppelt RD. Mycorrhizas of hepatics in continental Antarctica. Mycol Res 1999; 98 : 34-36.

84. Withers LA. In vitro Collecting-Concept and Background. In: Vitro Collecting Techniques for Germplasm Conservation; Pence, V.C., Sandoval, J.A., Villalobos, V.M., Engelman, F., Eds.; International Plant Genetic Resources Institute: Rome, Italy, 2002; p16-25.

85. Withers LA, Engelmann F. In vitro conservatipon of plant genetic resources. In Altman A (eds.) Biotechnology in Agriculture. Marcel Dekker Inc. New York, 1997; p57-88.

86. Withers LA, Engelmann F. In vitro conservation of plant genetic resources. In: Altman A (ed) Biotechnology in agriculture. Marcel Dekker, New York 1988; p57-88.

87. Wood CB, Pritchard HW, Miller AP. Simultaneous preservation of orchid seed and its fungal symbiont using encapsulation-dehydration is dependent on moisture content and storage temperature. Cryo Lett 2000; 21 : $125-136$

88. Zschocke S, Van SJ. Cryptocarya species-substitute plants for Ocotea bullata? A pharmacological investigation in terms of cyclooxygenase-1 and-2 inhibition. J Ethnopharmacol 2000; 71: 473-8. 